\title{
Ristiriitoja venäläisessä rap-musiikissa
}

Toni Mäkäräinen

Venäjän parlamenttitalon portailla nuori nainen kaataa päälleen nestettä samalla laulaen kuiskaamalla: "Minä valelen silmäni kerosiinilla, palakoon kaikki, palakoon kaikki / Minua katsoo koko Venäjä, palakoon kaikki, palakoon kaikki." ${ }^{\text {K }}$ Kseinen pätkä on venäläisen kokeellista musiikkia tekevän Ic3peak-yhtyeen "Smerti bolše net" ("Kuolemaa ei enää ole") -musiikkivideon alku. Provokatiivisuus ei lopu tähän. Videossa syödään raakaa lihaa Leninin mausoleumin edessä, poltetaan kannabis-sätkää Kansojen ystävyyden suihkulähteellä ja juodaan verta Moskvajoessa Kremlin vastakkaisella rannalla. Yhtye on kokenut videon julkaisun jälkeen runsaasti vastoinkäymisiä konserttiensa suhteen. Permissä heidän konserttinsa 27.11.2018 keskeytettiin ilman mitään ilmoitettua syytä. Sama on tapahtunut myös Kazanissa ja Nižni Novgorodissa. Novosibirskin konsertti, joka oli tarkoitus järjestää 1. joulukuuta, peruttiin paikallisten viranomaisten painostuksen vuoksi. Dožd-kanavan haastattelussa yhtyeen manageri Oleg Mitrofanov ilmoitti painostuksen tulevan FSB:n kautta Moskovan käskystä: "Ilmeisesti YouTube ei ole suostunut blokkaamaan videota, jonka vuoksi he kostavat [tällä tavoin]" (Dožd 2018).

Ic3peak ei ole kuitenkaan peruutusten tai keskeytysten kanssa yksin. Kun Haskin konsertti peruutettiin Krasnodarissa, hän kiipesi esiintymään auton katolle ja sai kahdentoista päivän tuomion lievästä huliganismista ja kolme päivää lisää hänen kieltäydyttyään lääkärintarkastuksesta (RIA Novosti 2018). Saman ovat kokeneet muun muassa räppäri Eldžei sekä Friendzone-yhtye, jonka sanoituksista Kemerovin paikallinen hallinto oli löytänyt: "alkoholiin, itsemurhiin ja samaa sukupuolta olevien suhteisiin liittyvää propagandaa" (Masaltseva 2018). Konserttien peruutukset ovat aiheuttaneet varsin runsasta keskustelua mediassa. 
Tämä taas on johtanut tilanteeseen, että jopa presidentti Vladimir Putin on ilmaissut oman näkemyksensä, jossa hän alleviivaa samaa kuin Kemerovin paikallinen hallinto: '[...] emme voi antautua itsemurha- ja huumepropagandalle" (TASS 2018). Putinin lausunto noteerattiin myös länsimaisessa mediassa ja muun muassa Helsingin Sanomat (Koppinen 2018), The Guardian -lehteä lainaten, julkaisi artikkelin aiheesta.

Viime vuosina venäläinen rap-musiikki on tasaisesti nostanut suosiotaan. Samainen trendi näkyy myös muualla maailmassa Suomi mukaan lukien. Niin Venäjällä, kuten Suomessakin, suurimmat hitit syntyvät melko tyhjänpäiväisistä aiheista, mikä ei kuitenkaan muuta sitä, että kappaleiden lyriikat ovat muuttuneet selvästi monimuotoisemmiksi. Osa aiheista, joista Venäjällä räpätään, saattavat tuntua eurooppalaisesta näkökulmasta erikoisilta. Patriotismi, ortodoksisuus ja maahanmuuttovastaisuus ovat vain osa kokonaiskuvaa, mikä toisaalta taas rakentaa siltaa venäläisen ja muun muassa serbialaisen rap-musiikin välille.

Vaikka venäläistä underground-musiikkia onkin verrattu neuvostoliittolaiseen rokkiin, on todettava ajan muuttaneen itse musiikkia käsitteenä. Internet on tehnyt julkaisemisesta helppoa, mutta samalla se on luonut uuden haasteen - audiovisuaalisen kokonaisuuden. Ic3peak luokitteleekin itsensä "audiovisuaaliseksi terroriksi ja futuristiseksi oopperaksi". Sanoitusten ohella myös musiikkivideot ovat nousseet uudelle tasolle. Lisäksi kollektiivit, kuten Dead Dynasty, jossa musiikki, pukeutuminen ja visuaalinen samankaltaisuus ovat kaikki osa yhtä kokonaisuutta, on taas ammentanut internetin estetiikasta eli on näin ollen sosiaalisen median synnyttämä.

Tässä esseessä käsittelen venäläistä rapia kolmesta eri perspektiivistä - sanoitusten, suuntausten ja yhteiskunnallisten tekijöiden kautta. Keskityn etenkin sanoituksia tarkastelemalla tuomaan esille, millaisia asenteita venäläisillä räppäreillä on, mitä aiheita he musiikissaan käsittelevät ja millä tavalla he edustavat hiphop-kulttuuria. Tämän avulla venäläistä rapmusiikkia voi tarkastella myös yhteiskunnallisessa kontekstissa. Punaisena lankana toimii ajatus genren - ja sen edustajien - ristiriitaisuudesta, joka ilmenee rap-artistien esittämien ideologioiden ja tekojen kautta. Tämä tulee esille esimerkiksi genressä esiintyvän nationalismin muodossa, joka ei lähtökohtaisesti sovi yhteen hiphopin alkuperäisten ideoiden kanssa. Lisäksi asetan venäläisen rapin myös globaaliin kontekstiin, sillä mikään ei synny rapissa itsestään. Tästä hyvänä esimerkkinä toimii esimerkiksi suurta suosiota YouTubessa saanut battlerap-kanava Versusbattleru, jonka katselluin video on parhaimmillaan kerännyt 45 miljoonaa näyttökertaa ${ }^{3}$ - luku, joka puhtaasti freestyle-rapin osalta on kyseisessä suuntauksessa jopa maailmanlaajuisesti korkea.

\section{Venäläisen hiphopin alkutaival}

Venäläisen hiphop-kulttuurin ja -musiikin synnyn voi ajoittaa 1990-luvun alkuun. Vaikka on sanomatta selvää, että spoken word -suuntaus juontaa juurensa niin runouteen kun chansontyylilajin esiintyjiin, niin myös Venäjällä on hiphopia syytä käsitellä omana ilmiönään. Vaikka varsinainen hiphop syntyikin Neuvostoliiton hajoamisen jälkeen, ensimmäisenä hiphopjulkaisuna pidetään yleisesti Tšas Pik -yhtyeen albumia Rap vuodelta 1984, joka - vaikkakin lainasi enemmän kuin selkeästi The Sugarhill Gangin "Rapper's Delight" -kappaletta - oli kuitenkin äänimaailmaltaan lähempänä neuvostorockia. (Ewell 2017, 45.)

Rapin ensimmäistä "aaltoa", johon kuuluivat esimerkiksi Maltšišnik, Bogdan Titomir ja Mister Maloi, voi luonnehtia äänimaailmaltaan tyypilliseksi 1980-luvun alun hiphopiksi ja sanoituksiltaan seksuaalisesti virittäytyneeksi, osittain parodiamaiseksi punchline-rapiksi - 
samanlainen kehitys tapahtui myös Suomessa (esimerkiksi MC Nikke T ja Raptori). Vaikka edellä mainitut artistit voi karkean jaottelun avulla luokitella kevyempää linjaa edustaviksi, myös vakavampaa musiikkia tehtiin. Näistä Bad Balancea ja ennen kaikkea heidän debyyttialbumiaan Naljotšiki Bad B (1994) voi pitää venäläisen hiphopin yksittäisenä merkittävänä albumina. Tuotannoltaan albumi ei sinänsä eronnut merkittävästi kevyemmistä julkaisuista, mutta oli sanoituksiltaan yhteiskunnallisempi. Varsinaisen undergroundin edustajaksi 1990-luvulla nousi kuitenkin moskovalainen D.O.B. Community -kollektiivi, johon kuuluivat muun muassa räppäri Ligalaiz ja duo Raby Lampy. (Gontchar 2017, 182.)

2000-luku nosti rapin profiilia Venäjällä yleisemmin esille ja yhdysvaltalaisten artistien vanavedessä myös venäläinen hiphop alkoi kehittyä populaarimpaan suuntaan. Käymättä tätä aikakautta tarkemmin läpi populaarin suuntauksen osalta on nostettava esille kuitenkin eräs kaupunki, jossa venäläisen rap-musiikin luonne siirtyi lähemmäs vakavampaa tematiikkaa. Moskovan glamourin sijasta betoninen, kylmä ja ongelmainen Omsk synnyttää yhtyeen Iezekiil 25:17 ${ }^{4}$,joka temaattisesti liikkuu patriotismin ja ortodoksisuuden maastossa. Yhtyeeseen kuuluvat räppärit Blednyi (suom. "Kalpea", Andrei Pozdnuhov) ja Ant (Anton Zavjalov), ja se on ollut olemassa vuodesta 2002 asti. Vuodesta 2009 lähtien yhtye on tunnettu nimellä 25/17.

Sanoitusten osalta heitä ei voi verrata suomalaisiin artisteihin. Esimerkkeinä toimivat kappaleet kuten "Bud belym!" ("Ole valkoinen!") tai "Prosypaites" ("Herätkää"), jossa riimitellään muun muassa seuraavanlaisesti:

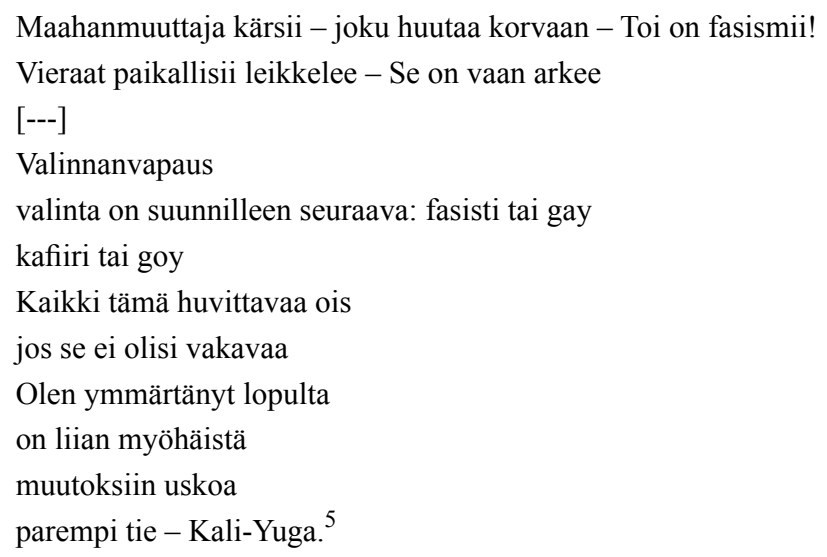

Tämän tyyppiset retoriset keinot sijoittuvat suomalaisessa kontekstissa ennemminkin äärioikeistolaiseen propagandaan kuin yhteiskuntakriittiseen rappiin.

\section{Omsk, uskonto ja isänmaa}

Nationalismi venäläisessä rap-musiikissa ei ole mikään uusi ilmiö. Jo vuonna 1992 Maltšišnik julkaisi kappaleen "Seks-kontrol", jossa varoitellaan valkoihoisia harrastamasta seksiä tummaihoisten kanssa ja sekoittamasta verta keskenään. 2000-lukulaisen nationalismin erottaa aikaisemmista konteksteista sen vakavuus, aggressiivisuus ja hengellisyys. Tämän kaltainen suuntaus muistuttaa vahvasti serbialaista hiphop-kulttuuria, jota esimerkiksi Dragana Cvetanović (2014, 3-15) käsittelee artikkelissaan "Petturien vai patrioottien räppi?" Siinä hän vertailee kahta serbialaisen rapin yhteiskunnallista ääripäätä - progressiivista (Marčelo) ja uuskonservatiivis-nationalistista (Beogradski Sindikat). 1990-luvun tapahtumien vuoksi 
Serbian nationalismi on konkreettisempaa kuin Venäjällä, ja retoriset keinot liittyvätkin oleellisesti Suur-Serbia-aatteeseen ja siihen liittyviin myytteihin. Venäjää ja Serbiaa yhdistää kuitenkin ortodoksisuus, "kansan arvojen puolesta taisteleminen", seksuaali- ja etnisten vähemmistöjen vastaisuus ja ehkä yleisemmin - vastakkainasettelu "teihin" ja "meihin". Ei olekaan yllättävää, että 25/17 teki yhdessä Beogradski Sindikatin ja useiden muiden omskilaisten artistien kanssa kappaleen "My pobedim!" (’Me voitamme!"), jonka sanoituksissa Blednyi riimittelee:

\author{
Hinttejä vihitään kirkoissa \\ Ettekö ole iloisia? Hä? \\ Se on rakkautta. Ei! \\ Ihmiset ovat veljiä. Ei! \\ Tasa-arvo. Paskaa! \\ Uskonto! Minun perheeni! \\ Minun isänmaani."6
}

Yhteistyötä Blednyi kommentoi seuraavasti:

[---] jos kirjoitamme yhteisiä biisejä joidenkin kanssa, jotka eivät ole venäläisiä, niin juuri tällaisten ihmisten kanssa. Neekereiden kanssa meillä ei ole mitään kirjoitettavaa - ei ole mitään yhteistä kiintopistettä. (Nikitin 2009.)

25/17:n Blednyi on sanonut haastattelussa Raamatun vaikuttaneen häneen eniten kaikesta kirjallisuudesta (Korobov-Latyntšev 2016a, 155). Samalla yhtye on jo siirtynyt pois venäläisestä rapista, joka hänen mukaansa on - ja aina tulee olemaan, "ikuinen apina, joka jäljittelee ihmistä” (emt. 158). Tällä hän tarkoittaa sitä, kuinka venäläiset räppärit hänen mukaansa matkivat amerikkalaisia tummaihoisia räppäreitä. On huomautettava, että 25/17:n tuotanto on nykyään siirtynyt lähemmäs rockin ja chansonin äänimaailmaa. Samalla myös sanoitukset ovat muuttuneet kohti hengellisempää ja runollisempaa sisältöä. Folkloresta vaikutteita ottanut äänimaailma (ja myös esimerkiksi levynkansien estetiikka) on korvannut hyökkäävän ja pauhaavan biitin. Lisäksi yhteistyö rock-muusikoiden kanssa ja muun muassa Josif Brodskin "Ne vyhodi iz komnaty" -runoon perustuvan singlen sanoittaminen on muuttanut 25/17:n yhä enemmän salonkikelpoiseksi. Asiaa voi tarkastella seuraavasti: äärioikeistolaisen retoriikan sijaan he ovat siirtyneet lähemmäksi venäläisistä perinteistä koostuvaa kokonaisuutta ja tällä tavoin alleviivanneet omaa taustaansa.

Vuonna 2009 Omsk esitteli myös toisen duon nimeltä Grot (Vitali Jevsejev ja Dmitri Geratštenko). Heidän uransa lähti käyntiin 25/17:n perustaman levy-yhtiö ZASADAProductionin kautta, joka kuitenkin on jo lopettanut toimintansa. Grotin tuotanto on käynyt läpi samanlaisen prosessin kuin edeltäjänsä, joskin alkuaikojen äänimaailma eroaa hiukan heidän kollegoistaan. Temaattisestikin Grot liikkuu tutussa maastossa: aiheina ovat uskonto ja patriotismi, mutta lisäksi myös päihteettömyys on heille yksi keskeisimmistä teemoista. Omien sanojensa mukaan myös he ovat nuorempina käyneet läpi päihteistä johtuvat ongelmat - aihe, jota he reflektoivat etenkin alkuaikojen tuotannossa (Nikitin 2010). Päihteidenvastaisuus yhdistyi heidän tuotannossaan aggressiiviseen ja provokatiiviseen ulosantiin, kuten esimerkiksi kappaleessa "Alkotester": "Läpi pihojen kellareista parvekkeille asti jyrisee / lentotukikohdasta uuden kieltolain ääni / jos ei erota Kotimaataan pöntöstä / uudelleen koulutetaan tai karkotetaan vittuun."7 
Alkuaikojen Grot oli äänimaailmaltaan kylmää ja kolkkoa. Tämä ei varsinaisesti ole yllättävää, sillä se kuulostaa siltä mitä siltä odottaakin - siperialaisessa ilmastossa tuotetulta aggressiiviselta avautumiselta yhteiskunnasta. Samanlaista tunnelmaa voi havaita myös Suomessa Julma-Henrin debyyttilevyllä Al-Qaida Finland (2007), joka tosin on sanoitusten osalta vastakohta Grotille, sillä se on vasemmalle kallistuvaa, vieläkin provokatiivisempaa, aggressiivisempaa ja ironista. Yhdistävänä tekijänä on kuitenkin yhteiskuntakriittisyys ja äänimaailman samankaltaisuus, joka molemmissa tapauksissa kuulostaa pohjoisen ilmaston betonisten lähiöiden tuotokselta.

Päihteidenvastaisuuden lisäksi Grot toi varsin selkeästi esille uskonnollisuuden ja patriotismin. Heidän ensimmäiset julkaisunsa olivat täynnä varsin suoriakin mielipiteitä, kuten kappaleessa "Za tšas do nastuplenija" ("Tunti ennen hyökkäystä"), joka loppuu sanoihin: "Tänä yönä rukoillessamme / sytytämme kynttilät / jotta kaikenlaisilla erirotuisilla paskiaisilla / ei olisi enää mitään mitä hengittää."8 Kappaletta voi pitää kokonaisuudessaan samanaikaisesti sekä sodanjulistuksena että yhtyeen itsetietoisena manifestina siitä, mitä he edustavat. Grot ei kuitenkaan syyttänyt kaikesta pelkästään maahanmuuttajia, vaan myös venäläiset saivat oman osansa. Kappaleen syntyhetkellä YK:n lähteisiin perustuen Venäjä oli ensimmäisellä sijalla maailmassa opioidien käytön suhteen, jos katsoo pelkästään käyttäjien lukumäärää9 ${ }^{9}$ Heroiinin salakuljetus Afganistanista kulkee Keski-Aasian kautta Venäjälle (UNODC 2009, 44-50). Kazakstanin jälkeen ensimmäinen Venäjällä sijaitseva miljoonakaupunki on Omsk, jossa päihdeongelmat eivät luonnollisestikaan tämän vuoksi rajoitu pelkkään alkoholinkäyttöön. Näin ollen ei voi pitää ihmeenä myöskään nuorisolle suunnattua valistusta rapin muodossa, jossa Jumala ja rakkaus isänmaata kohtaan korvaavat epäterveelliset tavat.

Grot, kuten 25/17, on edennyt näennäisen mustavalkoisesta maailmankuvastaan eteenpäin. Nykyään heidän aiheensa ovat muuttuneet monimutkaisemmiksi ja he käsittelevätkin tuskastellen olemassaolon merkitystä maapallolla. Ensimmäisten julkaisujen jokaisessa kappaleessa esiintyvät rukoilut ovat vaihtuneet moniulotteisemmiksi apokalyptisiksi pohdinnoiksi. "Ni s kem" ("Ei kenenkään kanssa") -kappaleen sankarin kyllästyttyä nykyajan hektisyyteen, hän poistuu ovesta:

Avaruus sykkii oven takana, tähtikuvioita esittävät lumisateen hiutaleet

pienen kalpean pisteen kohdalta löydämme kaikki itsemme yhteisestä haudasta

aalto osuu laituriin - ovat hiekanjyvät pohjalle vetäytyneet

herään jostain muualta enkä erota valtavaa elämää pienestä unesta. ${ }^{10}$

Kappale loppuu sanoihin, "tunnen, kuinka joku katsoo minua avointen ovien takaa"11 ja palauttaa uskonnollisen motiivin hyvinkin simppelillä metodilla, jota he yrittävät peitellä rakentelemalla kerroksittain monimutkaisempia riimejä.

Tästä syystä Grot ja 25/17 profiloivat itsensä venäläisen räpin yläpuolelle. He sanoutuvat irti hiphopin kulttuuriperinnöstä ja pyrkivät hivuttautumaan osaksi venäläistä kulttuuriperimää. Rap on heille vain tapa lukea runoja, ja rapia on huomattavasti helpompi tuottaa kuin esimerkiksi rock-musiikkia. Ottaen huomioon kummankin yhtyeen ideologiset taipumukset ja pyrkimyksen mennä eteenpäin filosofisella tasolla ei ole yllättävää, ketkä puhuvat yhtyeiden - etenkin 25/17:n - puolesta.

Hyvänä esimerkkinä toimii filosofiksi itseään nimittävä Andrei Korobov-Latyntšev, joka on kirjoittanut (tarkemmin ottaen koonnut haastatteluista sekä ylistävistä arvioista) kirjan Russki rep: Filosofskije otšerki (2016a). Lähtökohtaisesti kirja lupailee filosofista ulottuvuutta 
venäläiseen rap-lyriikkaan, mutta todellisuudessa kirja on patrioottisten räppäreiden ylistystä ja heidän luonnehtimistaan nykyajan filosofeiksi, jotka kulkevat Dostojevskin jalanjäljissä. Korobov-Latyntsevin lisäksi ylistäviä sanoja on jaellut myös äärinationalistinen kirjailija Zahar Prilepin, joka on varsin ristiriitainen persoona myös kotimaassaan.

Korobov-Latyntšev kirjoittaa, kuinka hiphop-kulttuurin eri osa-alueet, kuten graffitien maalaaminen ja breakdance, ovat kokonaisuudessaan vain nuorten hauskanpitoa ja näin ollen niitä ei tarvitse ottaa tosissaan (2016a, 35-6). Juuri siksi muun muassa 25/17 on jo rikkonut rajat ja liikkunut eteenpäin, sillä rap on hänen mukaansa genre-rajoissaan ahdas ja kaikki ketkä eivät ota edistysaskelia ovat naurettavia eivätkä kykene tuomaan filosofista ulottuvuutta tuotantoonsa (emt., 53). 25/17:ää hän kuvailee paljonpuhuvasti "yhdeksi viimeisistä nerokkaista taiteellisista läpimurroista historiallisen kristinuskon kontekstissa" (emt., 54).

25/17:n tapauksessa voimme tosiaankin puhua kehityskaaresta, jossa on muutama eri vaihe. Heidän alkuaikojen tuotantonsa käytti hyväkseen rapin keskeisiä ominaisuuksia: protestointia, yhteiskuntakriittisyyttä ja 90-luvun gangsta rapille tyypillistä aggressiivista uhoamista. Tämän kaiken he tekivät tavanomaisessa formaatissa niin rytmityksien kuin riimirakenteiden osalta. Nationalistinen konteksti ja välinpitämättömyys hiphopin juuria kohtaan saa kysymään missä menee alun perin vähemmistöjen protestiksi kehittyneen kulttuurin lainaamisen tai omimisen raja? Onko 25/17:n musiikki kulttuurista appropriaatiota vai voiko rapin erottaa omista juuristaan ja sulauttaa omaan ideologiaan ilman näiden kahden vuorovaikutusta, etenkään jos se on ristiriidassa alkuperäisen tarkoitusperän kanssa?

Lainaaminen on osa kulttuurien välistä dialogia, joka hiphopissa tulee esille etenkin samplejen eli toisista kappaleista lainattujen musiikkipätkien muodossa. Tällä tavoin se myös muodostaa linkin genrejen ja aikakausien välille tehden sen aiempia artisteja ja heidän musiikkiaan kunnioittaen. 25/17 voi lainata formaattia, mutta tekemällä näin se myös identifioituu tahtomattaan osaksi kulttuuria, josta se ei sano välittävänsä. Hiphop on ja tulee olemaan kiinni omissa juurissaan, protestiäänenä etnisille vähemmistöille. Näin ollen äärioikeistolainen retoriikka on muodon kanssa ristiriidassa, vaikka sitä kuinka perustelisikin osaksi venäläistä kulttuuriperintöä.

25/17:n filosofisia ulottuvuuksia sekä runollisia ominaisuuksia voi rapista "irtautumisen" jälkeen tarkastella osana venäläistä kulttuurillista jatkumoa, mutta silloin on syytä nostaa esiin ne motiivit, jotka ajavat Korobov-Latyntševin kaltaiset ihmiset tarkastelemaan uuden sukupolven venäläistä patrioottista rap-formaatin kautta esitettävää "filosofista" ääntä. Korobov-Latyntševin omaa filosofiaa voi tarkastella suuntausten ja niitä edustavien ajattelijoiden kautta ymmärtääkseen kokonaisuuden. Hänen ajattelunsa rakentuu kansallisbolševismin (Zahar Prilepin, Eduard Limonov ja Jegor Letov), eurasianismin (Aleksandr Dugin) ja slavofilian (Dostojevski) kautta (Korobov-Latyntšev 2016b). Yksinkertaistettuna voidaan puhua Russki mir -ajattelutavasta, johon tässä tapauksessa sisältyy venäläinen imperialismi, vahva ortodoksisuus ja käsite vsetšelovek, ajatus venäläisestä ihmisestä kaikkien kansojen veljenä - lopullisessa muodossa myös tiennäyttäjänä. Hän sanoo itse muuttaneensa Donetskiin tukeakseen Novorossijaa ja kehottaa tähän myös muitakin (Korobov-Latyntšev 2018).

Asettamalla nationalistisen rapin osaksi filosofista jatkumoa on mahdollista viestiä nuorelle kuulijakunnalle, että he ovat osa jotain suurempaa ja syvällisempää. Tämä on mielipidevaikuttamista, jota kautta henkilöt, jotka eivät välttämättä lue Dostojevskia, voivat kuitenkin identifioitua samaan traditioon. Jos rap on formaattina trendikäs tapa puhua nuorille, sen kontekstin perusteleminen edellä mainituilla tavoilla mahdollistaa myös radikaalimpien suuntausten hyväksymisen. 25/17 ei ihaile Venäjän valtiota, vaan kuten Beogradski Sindi- 
katin tapauksessa "puhuu kansan äänellä”. On huomautettava, että Venäjän oikeusministeriö on kieltänyt joitain heidän kappaleitaan ekstremistiseen sisältöön vedoten ${ }^{12}$. Tämä omalla tavallaan pelaa 25/17:n pussiin - "patriootit" ovat vihollisia jopa omassa maassaan ${ }^{13}$.

\section{Lyyrisyyttä, kaaosta ja taiteellisia ambitioita}

Korobov-Latyntševin (2016a) kirjaa tulee tarkastella kokonaisuutena kriittisesti, mutta se sisältää erään artistin, josta voi tosiaankin puhua tietynlaisen lyyrisyyden termein. Haski (Dmitri Kuznetsov) on venäläisessä räpissä ristiriitainen hahmo monellakin tapaa. Hänen henkilökohtaiset mielipiteensä eivät tunnu löytävän järkevää keskitietä, hänen tempauksensa ovat jatkuvaa tasapainottelua taiteellisen ja tekotaiteellisen välillä, suhde viranomaisiin on vähintäänkin vaikea, mutta itse musiikki on epätavallista ja sanoitusten osalta valtavirrasta poikkeavaa. Lisäksi hänen tapansa käyttää ääntä ja rapiin kuuluvia taustahuudahteluita osana kappaleen rytmistä kokonaisuutta, eikä pelkästään äänimaailman lisäämiseen, rakentaa omalla tavallaan monimutkaisen kokonaisuuden, jota tukee myös ajoittain epätavanomaiset rytmitykset taustoissa.

Haski nousi tunnetuksi kappaleella "Pulja-dura" ("Luoti-urpo"), jonka musiikkivideo esitteli kaljun, Adidas-pukuisen slaavikyykyssä istuvan nuoren - slangissa gopnikin - naamioituneiden miesten kanssa heilumassa. Video leikittelee rapin esteettisillä kliseillä yhdistäen tähän myös edellä mainitun venäläisen gopnik-estetiikan. Tähän myös perustuu hänen julkinen kuvansa. Itse kappale taas on hyvinkin tyypillistä Haskia rakenteellisesti, joskin helpommin lähestyttävä kokonaisuudessaan. Se sisältää helpon kertosäkeen ('En halua olla komea / en halua olla rikas / haluan olla rynkky / joka ampuu naamoihin"14) ja misantrooppiset sekä vulgaarit säkeistöt, joissa hän riimittelee ihmisten muuttuneen harmaaksi massaksi:

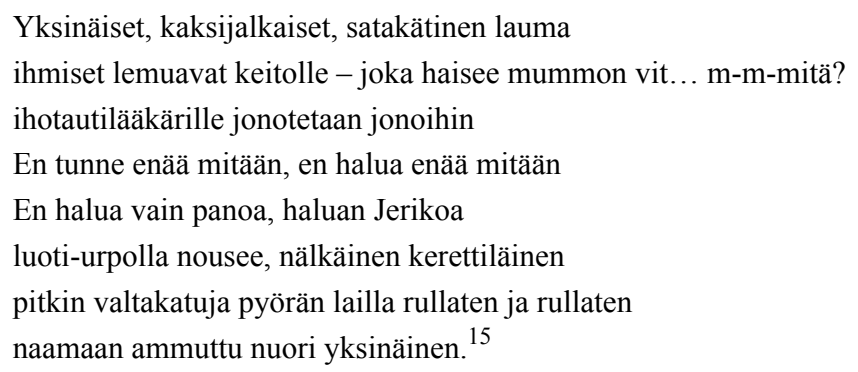

"Pulja-dura" on laadukkaasti tuotettu ja suoraviivainen kappale, jonka tarkoitus on koukuttaa kuulijoita. Se myös osuu sekä äänimaailmalta että sanoituksilta 25/17:n ja populaarimman rapin välimaastoon, mutta pysyy kummastakin hitusen etäällä, omassa maailmassaan. Kappaleen musiikkivideo osoitti myös visuaalisen puolen tukevan kokonaisuutta kaikessa sekavuudessaan. Musiikkivideoiden osalta on syytä nostaa esille kappale "Krot 17" ("Myyrä 17"). Sanoitukset kertovat henkilön sisällä asuvasta "myyrästä": joka pitää isäntäänsä hallinnassa: "juuri kun nukahdan, juuri kun hiljennyn / sisälläni käytäväverkostoja hän sokeasti teroittaa / ohuet kankaani omeletiksi sekoittaa / tunneleita jyrsimällä ulkopuolelle kurottaa" ${ }^{\text {. }}$. Laadukkaasti animoidussa videossa Haski pakenee jättiläismäistä olentoa punamustassa, psykedeelisessä ja paranoidisessa ympäristössä. Video on moskovalaisen Bakehouse-tuotantoyhtiön käsialaa, joka on tehnyt mainoksia Googlelle, Huaweille ja Adidakselle, joten ei ole ihme, että myös lopputulos on ammattimainen ${ }^{17}$. 
Venäläisessä rapissa Haskin voi nähdä varsin taitavana niin sanoitusten, kuin visuaalisen puolen osalta. Tämä ei poista kuitenkaan hänen persoonansa ongelmallisuutta ja ristiriitaisuutta kokonaiskuvassa. Artisti kokee itsensä suuremmaksi kuin genre, jossa hän toimii. Hänessä yhdistyy venäläisen 1990-luvulla syntyneen nuorison ideologinen välinpitämättömyys ja ylitsevuotava halu olla rajoja rikkova taiteilija - yhdistelmä, joka hänen osaltaan synnyttää varsinaisen kaaoksen.

Hänen tempauksensa viestivät hänen taipumuksistaan performanssitaiteen suuntaan. Syyskuussa 2018 hän julkaisi Instagramissa videon, jossa hän poistaa tietokoneelta uuden albuminsa Jevangelije ot sobaki ("Evankeliumi koiralta"). ${ }^{18}$ Hänen sanojensa mukaan hän halusi tulla "uudestaan omaksi isännäkseen", samalla paljastaen albumin konseptina olleen "Jeesuksesta Moskovassa [20]10-luvulla" (Flow.ru 2018). Tämä selkeästi Gogolista ja Bulgakovista ammentava teko oli performanssin ja itsensä promoamisen yhdistelmä, joka selvästi myös onnistui, sillä albumia ei koskaan julkaistu, mutta kiinnostus häntä kohtaan pysyi korkealla. Parin videoperformanssin ja perinteikkäästi nimetyn "Poema o rodine" ("Runoelma kotimaasta") -kappaleen jälkeen Haski muutti musiikillisesti suuntaa ja julkaisi muun muassa "Ubit repera" ('Tappaa räppäri”) -nimisen kappaleen sisältävän EP:n, jonka äänimaailma on ennemminkin punk-musiikkia.

Kuten nationalistisen siiven edustajat, myös Haski pyrkii pois rapin genrestä, mutta tämän lisäksi hän jakaa näiden kanssa monia näkemyksiä, kuten Donetskin separatistien tukemisen. Tästä hyvänä esimerkkinä voi pitää "Motorola"-kappaletta, jossa hän lukee samannimisen, vuonna 2016 tapetun separatistijohtajan runoja. The Village -lehdelle antamassa haastattelussa hän toteaa, ettei "näe mitään ristiriitaa siinä, että osallistuu Bolotnajan mielenosoituksiin ja tukee Donetskin kansantasavaltaa" sekä alleviivaa, kuinka "oikea ja vasen ovat kuolleita ideologioita" (Fedorenko 2016) - teesi, joka on varsin yleinen venäläisen nuorison keskuudessa.

Tämä kaikki tekee hänestä ristiriitaisen hahmon, mutta tämä on toisaalta myös hänen taiteellinen roolinsa, kuten "Krot 17"-kappaleen sanoitukset omalla tavalla kertovat. Moni hänen ikäluokkaansa kuuluva jakaa samanlaisen häilyvän kuvan maailmasta, mikä tekee Haskista samaistuttavan kohteen. Lopputulos on samalla tavalla ristiriitainen - omassa genressään hyvinkin taitava, mutta puskiessaan ulos mukavuusalueeltaan taiteellisuus alkaa vaikuttamaan väkinäiseltä ja lähinnä omaa egoa pönkittävältä toiminnalta.

\section{Nihilismiä, kirjallisuutta ja konekiväärimiehiä}

Battle on hiphopin muoto, jossa kilpailijat pyrkivät improvisaation eli freestylen avulla voittamaan vastustajansa verbaalisesti niin sisällön kuin muodon tasolla. Yleisesti ottaen tähän kuuluvat alatyyliset kommentit, mutta myös poikkeuksia löytyy. Tämä on hiphop-kulttuurin osa-alue, joka jopa globaalisti katsottuna on harvinaisen suosittua Venäjällä. Tältä osin on syytä nostaa esiin 6.8.2017 käyty Oxxxymironin ja Slava KPSS:n välinen tunnin mittainen taisto, jossa he kisailivat a capellana ja joka kiinnitti laajempaa huomiota myös venäläisessä valtavirtamediassa. ${ }^{19}$

Kilpailijoita pidetään yleisesti ottaen venäläisen battlen kärkiniminä. Slava KPSS eli Gnoini (Vjatšeslav Mašnov) on lähtökohtaisesti profiloitunut nimenomaan tällä kentällä, kun taas Oxxxymironia (Miron Fjodorov) voi pitää kokonaisvaltaisempana artistina, joka battlen lisäksi keskittyy tarkasti myös levytettävään rapiin. He ovat tyyleiltään ja lähtökohdiltaan toistensa vastakohdat, mutta ovat kumpikin omalla tavallaan lahjakkaita riimittelijöitä. Slava KPSS:ää voisi luonnehtia venäläisen nihilismin perilliseksi ja venäläisen rap-musiikin trolliksi, joka 
vinoilee muille ja kulkee omaa polkuaan muista välittämättä. Oxxxymironista pidetään omaperäisenä tyylinsä ja sanoitustensa vuoksi. Hänestä on todettava myös sen verran, että hän on kasvanut Saksassa ja Lontoossa ja valmistunut Oxfordin yliopistosta pääaineenaan englantilainen kirjallisuus (Walker 2012). Tämän vuoksi ei liene ihme, että hänet luokitellaan usein "intellektuelliksi räppäriksi".

Näiden kahden artistin välinen koitos sisälsi varsin laajan määrän eritasoisia riimejä, jotka vaihtelivat sisällöllisesti etnisyyteen liittyvistä ala-arvoisista kommenteista aina kirjallisuusviittauksiin asti. Slava KPSS:n käyttäessä hyvinkin aggressiivista ja vulgaaria kieltä - joka toki liittyy formaattiin - Oxxxymiron pystyi viemään läpi omat osuutensa ilman voimasanoja, mutta onnistui tästä huolimatta loukkaamaan vastustajaansa ala-arvoisilla riimeillä. Kokonaisuutta voi tarkastella kahdella tavalla: Slava KPSS:n tyyli oli lähempänä freestyle-rapia ja pystyi ehkä tämän vuoksi päihittämään opponenttinsa. Oxxxymiron taas näytti, kuinka lajityyppiä voi käyttää hyväksi ilman siihen liittyviä oletuksia.

Slava KPSS oli kokonaisuudessaan verbaalisesti kekseliäämpi, ja saattoi hyökätä Oxxxymironia vastaan myös jälkimmäisen tyylillä, kuten esimerkiksi käyttämällä hyväkseen Majakovskin runoa "Poezija"20. Lisäksi hän otti silmätikukseen Oxxxymironin konseptuaalisen albumin Gorgorod (2015), joka on dystopiakuvaus Mark-nimisestä kirjailijasta. Kyseistä albumia voi pitää merkittävänä tuotoksena venäläisessä rapissa, sillä se rakentuu tarinan ympärille ja sitä voi pitää ennemminkin runoelmana, kuin hiphop-tuotoksena. Se todistaa, kuinka Oxxxymiron on enemmän kuin battle-rapin edustaja - toisin kun Slava KPSS. Mutta miksi heidän kisansa on kerännyt jo lähes 40 miljoonaa katselukertaa ja miksi siitä puhuttiin niin paljon mediassa?

Sosiaalisen median lisäksi jopa RIA Novosti julkaisi useita artikkelia koitokseen liittyen (RIA Novosti 2017). Novaja Gazeta (Šenkman 2017) arvioi katselukertojen johtuvan ulkopuolisista tekijöistä. Artikkelissaan he toivat esille kuusi syytä, joista nostan esille kolme: politiikka, viha ja ksenofobia. On helppo kuunnella paatosta, jos se sisältää tuttuja teemoja, kuten Ukraina, Navalnyi ja mielenosoitukset. Samalla voi todeta, että vihamielisyyttä ja toista henkilöä loukkaava asenne kiehtoo venäläistä yleisöä - internetin keskustelupalstojen politiikkaan liittyvä keskustelukulttuuri antaa tästä varsin hyvän kuvan. Ksenofobia, joka paistaa tässäkin tekstissä jatkuvasti läpi, yhdistyy kyseisessä kontekstissa antisemitismiin, jolla on venäläisessä kulttuurissa pitkät perinteet.

Novaja Gazetan argumentit saattavat olla osin totta, mutta jättävät kokonaisuudessaan melko mustavalkoisen vaikutelman. Jos battle-formaattia tarkastellaan vain yhteiskuntakritiikin näkökulmasta, saattaa siinä kadota jotain lajille keskeistä - lyriikka. On sanomattakin selvää, että runomuodolla on venäläisessä kulttuurissa pitkät perinteet, ja vaikka rapia ei katsoisikaan runollisen perinteen jatkumona, voi tästä huolimatta todeta sen käyttävän monia samoja keinoja. Rap on internetsukupolven lyyrinen tapa ilmaista itseään. Myös Artemi Troitski (Fanailova 2017) jakaa saman ajatuksen ja vertaa räpin kielellisiä ominaisuuksia venäläiseen rockiin, jossa hänen mielestään: "muusikoiden ja kielen välinen suhde oli vaikeasti saavutettavissa." Lisäksi hän toteaa:

Se, mitä [...] rockista kehittyi, oli kirjallisuuskeskeistä, alakuloista, hidasenergistä [...] musiikkia, jota lännessä ei edes pidetä rockina. Rap tuo esille meidän kansamme intohimon ilmaista itseään sanan, tarkemmin ottaen maksimaalisten sanamäärien kautta, ja [tällä tavoin] löytää täydellisen reitin [ilmaisulle]. (Fanailova 2017.)

Noize MC:tä (Ivan Aleksejev) voi pitää venäläisen räpin vastapainona, sillä hänet voi nähdä genren progressiivisena edustajana. Hän vastustaa rasismia, esittää pasifistisia nä- 
kemyksiä ja kritisoi yhteiskunnassa esiintyviä ongelmia. Esimerkkejä fasismin vastaisista kappaleista ovat "Puškinski rep" ("Puškinin rap"), jossa hän esiintyy klassisena kirjailijana, joka kritisoi rasismia omien sukujuuriensa vuoksi, sekä "Edem 14/88" ("Eeden 14/88"), joka on luomiskertomuksen radikaali uudelleentulkinta. Siinä natsit vaihtavat Aatamin ja Eevan arjalaisiksi estääkseen muiden rotujen syntymisen, mutta he joutuvat pettymään, kun näin ei käykään (Ewell 2017, 47-52). Viime vuonna hän osallistui Venäjän armeijan tukemille Našestvie-festivaaleille, jossa hän esitti kappaleen "Ljudi s avtomatomi" ("Ihmiset ja konekiväärit") - äärimmäisen ironisen kappaleen armeijasta ja venäläisten yleisestä suhtautumisesta asevoimiin (Ševelev 2018). Kappale on hyvä esimerkki venäläisen nykymusiikin tavasta sanoittaa, joka ei rajoitu pelkästään hiphopin puolelle:

\author{
Konekiväärimiehet meidät pelastaa \\ konekiväärimiehiltä, jos tapahtuisi jotain pahaa \\ kaikki pahat konekiväärimiehet tapettaisi \\ seulaksi hyvät ne ampuisi \\ mutta jos pahat jostain syystä voittaisi \\ niin väärät olivat pahiksia \\ tämän hyvikset meille tarkasti kertoisi \\ ennen kun suvereniteetin riistäisi ${ }^{21}$.
}

Noize MC ei kuitenkaan ole puhtaasti rapia, kuten ei myöskään muutkaan kriittisen sanan edustajat, joista puhutaan venäjänkielisen rapin yhteydessä. Myös Ic3peak on ottanut vaikutteita rapista ja etenkin kappaleiden taustat toki myös kuulostavat nykyaikaiselta rap-musiikilta, mutta yhtye liikkuu ennemmin kokeellisessa elektronisessa musiikissa, kuin hiphopissa. ${ }^{22}$

\title{
Ristiriitainen internet-sukupolvi
}

Vaikka tämän esseen keskiössä onkin rap-musiikki, se on vain yksi osa nykyaikaisen venäläisen populaarimusiikin kenttää. On myös tärkeää havainnollistaa internetin vaikutusta nykymusiikin suuntauksiin. YouTube mahdollistaa Ic3peakin tyylisten artistien groteskit musiikkivideot, joita ei koskaan näytettäisi televisiossa. Samaa voi sanoa myös battle-formaatista, jonka kymmenet miljoonat katselukerrat kertovat, miten venäläinen nuoriso viettää aikaansa.

Internet on olennainen myös läntisten vaikutteiden osalta. Tästä voi nostaa esimerkiksi Dead Dynasty -kollektiivin, joka on velkaa Yhdysvaltalaiselle soundcloud rap -suuntaukselle (Turner 2017). Kyseinen suuntaus on syntynyt puhtaasti internetistä, joka näkyy muun muassa audiovisuaalisen kokonaisuuden kautta ja kuuluu sanoituksissa. Lyyrisesti sitä ei voi pitää erityisen kekseliäänä, sillä sen keskiössä ovat päihteet, jotka artistista riippuen joko lieventävät tuskaa tai luovat sitä. Dead Dynasty ei ole puhtaasti hiphop-kulttuurin tuotos. Myös Yhdysvalloissa genreen ovat vaikuttaneet esimerkiksi punk sekä raskaampi musiikki. Tämä on nähtävissä pukeutumisen osalta, mutta myös kuultavissa äänimaailmassa, joka on muuttunut raskaammaksi ja synkemmäksi.

Jos katsoo internetin vaikutusta artisteihin ja irtaantuu hiphopista, venäläisen populaarimusiikin kentälle on ilmestynyt Monetotškan kaltaisia artisteja, jotka äänimaailman osalta ovat saaneet vaikutteita pohjoismaisesta indie popista, mutta joiden musiikissa kuuluvat myös venäläiset vaikutteet. ${ }^{23}$ Sanoituksissa on runsaasti viittauksia venäläiseen kulttuurin kaanoniin, niiden maailmankuva on ironinen ja viittauksia viljellään tuon tuosta. Esimerkiksi 
Monetotškan debyyttialbumin kantta koristaa ikonia muistuttava maalaus.

Mitä tulee venäläiseen rap-musiikkiin, se on nähtävä yhtä ristiriitaisena lajityyppinä kuin siihen kuuluvat artistitkin. Yritys kehittää omaehtoista venäläiseen kulttuuriperimään kuuluvaa lajityyppiä, joka vain lainaa tyylipiirteitä on ongelmallinen, sillä se muuttaa rapin alkuperäisen idean täysin päinvastaiseksi. Näin se ei onnistu olemaan itsenäinen vaan muokkaantuu tahattomasti alkuperäisen irvikuvaksi. Rasistinen rap-musiikki on paradoksi, joka on pseudofilosofisten argumenttien jälkeenkin ainoastaan kuriositeetti.

Haski osoittaa omalla tyylillään, kuinka sanoitukset pystyvät olemaan kompleksisia, jopa runollisia. Venäjällä ristiriitaiset persoonat ovat aina olleet ihmisten mieleen ja tässä mielessä Haski sopii taiteellisesti tähän jatkumoon. Haskin tapauksessa on muistettava, että hän ei ole suoranaisesti yhteiskuntakriitikko. Hänen konserttiensa peruutukset johtuvat ennemminkin Venäjän poliittisesta tilanteesta kuin valtiovallan haastamisesta. Hänen henkilökohtaiset mielipiteensä huomioon ottaen ei ole ihme, että myös valtiollinen televisio on herännyt puolustelemaan häntä: Kremlin äänitorvena tunnettu televisiojuontaja Dmitri Kiseljov (2018) nousi puolustamaan Haskia ja muita rap-muusikoita argumentoiden, että venäläisen rapin juuret eivät ole tummaihoisten yhdysvaltalaisten kulttuurissa, vaan runoudessa. Hän luki lähetyksessä Majakovskia rapin formaatissa ja toi esille Haskin lisäksi muitakin esiintyjiä alleviivaten heidän patriotismiaan. Hän toi esille jopa Noize MC:n riimejä - kontekstista irrotettuna - kutsuen niitä teini-iän anarkismiksi ja itseironiseksi uhoamiseksi ja vertasi häntä venäläisen runouden "huligaaniksi" - Jeseniniksi.

Kiseljovin taktiikka nostaa venäläiset räppärit osaksi kansallista kaanonia perustelemalla heitä runouden uudeksi sukupolveksi normalisoi rapin suurelle yleisölle. Sanat eivät ole uhka yhteiskunnalle, ne ovat vain taidetta. Hän muistuttaa kuinka yleisön kiinnostukset muuttuvat ajan kuluessa ja räppärit kasvavat aikuisiksi. Tämä on siis vain vaihe, joka tulee aikanaan loppumaan. Kiseljov onnistuu luomaan kuvan hiphopista teiniuhoamisena, jota ei tarvitse politisoida sen enempää. Ristiriita on siinä, että käyttäessään Majakovskia esimerkkinä hän ikään kuin unohtaa runoilijan olevan yksi vallankumouksen symboleista, jonka sanoja pidetään enemmän kuin sanoina.

\section{Kyyninen, ironinen ja herkkä Venäjä}

Tässä esseessä esiintyneet artistit ja heidän sanoitukset ovat kriittisiä, mutta ketä kohtaan ja millä tavalla? Nationalistinen siipi maalaa synkkää kuvaa Venäjästä, jonka ongelmia ovat maahanmuuttajat ja päihteet, mutta ehdottomasti myös uskonnottomuus. Kritiikki kohdistuu todellisuudenkuvauksen kautta vallanpitäjiin, mutta keskeinen ongelma on tietynlaisen hengellisen ideologian puute. Kappaleiden asettaminen mustalle listalle saa rap-artistit vaikuttamaan marttyyreiltä, minkä avulla he voivat tuoda esille traditionaalisten arvojen puutteita vallanpitäjien toiminnassa.

Slava KPSS on internetissä seikkaileva sarkastinen ja ironinen hahmo, joka ei suoranaisesti kritisoi, vaan provosoi. Hänen tapauksessaan provokaatio kohdistuu enimmäkseen muihin räppäreihin, mikä on loogista, sillä hänen vahvuutensa on battle, jossa sisältö on toissijaista. Hän luo kuvaa, jossa hänen ei tarvitse vaivautua yhteiskuntakritiikkiin, sillä hänen mukaansa yhteiskunnassa nähtäviä epäkohtia ei tarvitse alleviivata erikseen. Tämänlainen asenne, jossa millään ei ole väliä, koska mihinkään ei voi vaikuttaa on Venäjällä varsin yleinen. Korruptio on aiheuttanut kyynisen tilanteen, jossa yhteenkään poliitikkoon ei luoteta. Esimerkiksi vuonna 2011 julkaistussa kappaleessaan "Lozungi" ("Iskulauseet") Slim kertoo, ettei välitä 
kuka on johdossa kiroten myös Nemtsovin ja Bolotnajan sekä Žirinovskin, ja kuinka hän ei ole äänestänyt eikä aiokaan äänestää, sillä vaaleista ei ole mitään hyötyä24 ${ }^{24}$ Oxxxymiron on taas todennut, ettei halua olla poliittinen, sillä se aiheuttaa taiteen devalvaatiota lisäten, että hänen mielestään sekä pro- että anti-Putin ovat kumpikin huonoja positioita (Walker 2012). Hänen dystopiansa on rakennettu kirjallisuudessa esiintyvien kaavojen kautta.

Kulttuurillisesti hiphop ei ole Venäjällä yhtenäinen ilmiö, vaan jakaantuu useampaan leiriin. Ristiriitaisuuksia löytyy niin suuntausten kuin yksittäisten artistienkin osalta. Tyylikeinoina muusikoilla on ironia ja naturalismi. Jopa Ic3peakin lyyrinen minä ei ole suoranaisesti hyökkäävä, vaikka yhtyeen provokatiivinen asenne näkyy musiikkivideoissa. Ironinen asenne ei kuitenkaan ole kuolemassa Venäjältä pois, sillä se on paras tapa tuoda asiansa esille myös nykyisessä tilanteessa. Terävin kritiikki syntyy siitä, että huomio kiinnitetään yhteiskunnassa vallitseviin absurdismeihin ja tunnetiloihin, mutta vahvasti politisoitunut yhteiskunta on myös hyvin herkkä, sillä siltä puuttuu itseironia. Tämä aiheuttaa tilanteen, jossa alueelliset viranomaiset saattavat tulkita minkä tahansa ironiselta kuulostavan riimin hyökkäykseksi. Tällainen kieltolaki kuitenkin vain syventää viranomaisten ongelmaa - sanan vahvuus ei ole mitattavissa millään barometreillä ja sen vuoksi se löytää aina tiensä ulos.

\section{Viitteet}

1 "Ja zalivaju glaza kerosinam, pust vsjo gorit, pust vsjo gorit / Na menja smotrit vsja Rossija, pust vsjo gorit, pust vsjo gorit."

2 Sitaatti yhtyeen Twitter-tilin biografiasta: https://twitter.com/ic3peakso (Tarkistettu 10.6.2019).

3 Oxxxymiron vs. Johnyboy Versusbattleru -YouTube-kanavalla: https://www.youtube.com/ watch? $\mathrm{v}=$ MVouMFKmaeI (Tarkistettu 10.6.2019).

4 Nimi on suora viittaus Hesekielin kirjan 25. luvun 17. jakeeseen: "Minä kostan heille kovalla kädellä, ankarasti minä rankaisen heitä, ja silloin, kostoni kohdatessa heidät, he tietävät, että minä olen herra." Tämän lisäksi perustajajäsen Blednyin mukaan sitaatti liittyy myös elokuvaan Pulp Fiction (USA, 1994), jossa kyseinen sitaatti kuullaan, ja Cypress Hillin kappaleeseen "Make a Move", joka on lainannut kyseistä sitaattia edellä mainitusta elokuvasta (Sajapina 2008). Haastattelu on julkaistu Huligan-lehdessä, mutta alkuperäistä lähdettä ei löytynyt. Blednyi julkaisi aina vuoteen 2016 asti yhtyeeseen liittyvät haastattelut LiveJournalissa blogikirjoituksena, joista selviää mm. toimittaja ja lehti, https://blednyi-2517.livejournal.com/2499.html (Tarkistettu 10.6.2019).

5 "Postradal prijezži - eto fašizm! - krik v uho / Jesli gosti režut mestnyh - eto bytovuha. [---] Svoboda vybora / a vybor primerno takoi: fašist ili gei / kafir ili goi / Vse eto bylo by smešno / jesli b ne bylo serjezno / Ja ponjal okontšatelno / tšto uže pozdno / nadejatsja na peremeny / k lutššemu - Kali-Juga."

6 "Pidorov ventšajut v hramah / Vy tšto ne rady? A? / Eto ljubov. Ne! / Vse ljudi bratja. Ne! / Vseobštšeje ravenstvo. Bred! / Vera! Moja semja! / Mojo otetšestvo."

7 "Gremit po dvoram ot podvala do balkona / S aviabazy golos novogo suhogo zakona / Tot, kto ne otlitšajet Rodinu ot sortira / Perevospitan budet ili nahui deportirovan."

8 "Etoi notšju v molitve / zažžjom svetši / Tšto by vsei raznoporodnoi mrazote / dyšat stalo netšem." 
9 YK:n raportissa todetaan, että lähteet vaihtelevat, mutta korkein arvio olisi 1,68 miljoonaa (UNODC 2009, 61).

10 "A za dverju pulsirujet kosmos / tut snegopad iz snežinok sozvezdi / Na blednoi malenkoi totške odnaždy nas zakopajut pod zemlju vseh vmeste / Udarit volna o pritšaly i smojet pestšinki na samoje dno / Ja prosnus uže gde-to ne zdes / i ogromnaja žizn mne pokažetsja malenkim snom.”

11 "No ja tšuvstvuju, na menja kto-to smotrit s toi storony nezakrytyh dverei."

12 Minjust Rossii, Federalnyi spisok ekstremistskih materialov: \#1730, \#3248, \#3780. https://minjust. ru/extremist-materials?field_extremist_content_value $=25 \% 2 \mathrm{~F} 17$ (Tarkistettu 10.6.2019).

13 Blednyin tiedote asiasta VKontaktessa: https://vk.com/id6047429?w=wall6047429_10203 (Tarkistettu 10.6.2019).

14 "Ja ne hotšu byt krasivym / ne hotšu byt bogatym / Ja hotšu byt avtomatom / streljajuštšim v litsa."

15 "Odinokije dvunogije, storukaja orda / Ljudi pahnut supom, kak staruhina mand... tš-tš-tšo? / Otšeredi v otšeredi k kožnomu vratšu / Ja nitšego ne tšuvstvuju, ja bolše ne hotšu / Ja ne hotšu perepihon, ja hotšu Ijerihon / Na pule-dure verhom golodnym jeretikom / I katitsja, i katitsja po prospektam kolesom / Odinoki junoša s prostrelennym litsom."

16 "Tšut tolko usnu, tšut ja tolko utihnu / On totšit slepuju hodov pautinu vo mne / Mjagkije tkani vzbivaja v omlet / On tunnel progryzajet vovne."

17 Tuotantoyhtiön kotisivut: http://bakehouse.moscow/ (Tarkistettu 10.6.2019).

18 Alkuperäistä videota ei ole enää saatavilla.

19 Versusbattleru -YouTube-kanavalla: Oxxxymiron vs. Slava KPSS: https://www.youtube.com/ watch? $=\mathrm{v} 4 \mathrm{rvTMBCJD0} \& \mathrm{t}=1859 \mathrm{~s}$ (Tarkistettu 10.6.2019).

20 "Ty ne žil nad slovesnoi rudoi v štolne / No pafosa tak dohuja, slovno utšilsja s Putinym v odnoi škole."

21 "Ljudi s avtomatami nas spasut / ot ljudei s avtomatami, jesli tšto / 'plohih' ljudei s avtomatami vseh ubjut / Iz nih 'horošije' sdelajut rešeto / a jesli vsjo-taki 'plohije' vdrug pobedjat / znatšit prosto 'plohimi' byli ne te / eto nam 'horošije' dohodtšivo objasnjat / pered tem, kak zabrat suverenitet"

22 Lisäksi esille nousee Vasja Oblomov (Ewell 2017, 52), joka kuitenkin nähdäkseni ei edusta hiphopkulttuuria, vaan chansonia.

23 Monetotška liitetään myös rap-musiikkiin ja hän on esiintynyt muun muassa Noize MC:n kanssa kappaleella "Ljudi s avtomatomi".

24 "Ja ne vešal Volodin portret na stenu / no ja tšastenko vižu Kreml tšerez grjaznuju lobovuhu / vmeste s Nemtsovym i Žirinovskim idite v pizdu / ja ne hodil na vybory i vrjad li poidu / stavit krestik naobum, tipa menja sprosili."

\section{Lähteet}

Cvetanović, Dragana (2014), Petturien vai patrioottien räppi? Idäntutkimus 21:1, 3-15.

Dožd (2018), "Prikaz sryvat kontserty idet iz Moskvy". V Novosibirske otmenili vystuplenije IC3PEAK, do etogo — v Kazani i Permi. - TV Rain 28.11.2018. https://tvrain.ru/news/prikaz_ sryvat_kontserty_idet_iz_moskvy_v_novosibirske_otmenili_v ystuplenie_ic3peak_do_etogo_v_ kazani_i_permi-475971/

Ewell, Philip (2017), Russian Rap in the Era of Vladimir Putin. - Hip hop at Europe's edge: music, agency and social changes. Ed. Milosz Misczynski, Adriana Helbig. Indianapolis: Indiana University Press, 45-62.

Fanailova, Jelena (2017), Bitva naroda. - Radio Svoboda 19.8.2017. https://www.svoboda. org/a/28680193.html 
Fedorenko, Nataša (2016), Ljubimoje mesto: Haski - ob obštšežitii MGU i odinotšestve. - The Village 29.12.2016. https://www.the-village.ru/village/weekend/favourite/254041-lyubimoe-mesto-haski

Flow.ru (2018), Vy dumajete, Haski vas trollil? Net, on pravda udalil svoi albom. - Flow 11.9.2018. https://the-flow.ru/news/husky-evangeliya-ne-budet

Gontchar, Alexandre (2017), Violence as Existential Punctuation, Russian Hip Hop in the Age of Late Capitalism - Hip hop at Europe's edge: music, agency and social changes. Ed. Milosz

Misczynski, Adriana Helbig. Indianapolis: Indiana University Press, 182-198.

Kiseljov, Dmitrij (2018), Kiseljov - o Haski i repe voobštše. - Vesti.ru 2.12.2018. https://www.vesti. $\mathrm{ru} / \mathrm{doc} \cdot \mathrm{html}$ ?id=3090102

Koppinen, Mari (2018), Vladimir Putin haluaa alkaa suitsia rap-musiikkia - syynä genrelle ominainen kielenkäyttö ja huumeet, jotka uhkaavat hajottaa koko kansakunnan. - Helsingin Sanomat 16.12.2018. https://www.hs.fi/kulttuuri/art-2000005934288.html

Korobov-Latyntsev, Andrei (2016a), Russki rep: filosofskije otšerki. Sankt-Peterburg: Renome.

Korobov-Latyntsev, Andrei (2016b), Vremja jevrazistvujet. - Sigma 23.2.2016. https://syg.ma/@ atpernat8/vriemia-ievraziistvuiet

Korobov-Latyntsev, Andrei (2018), Potšemu my prodolžajem ujezžat v Donbass. - Sigma 17.12.2018. https://syg.ma/@atpernat8/pochiemu-my-prodolzhaiem-uiezzhat-v-donbass

Masaltseva, Maria (2018), Gruppa «Frendzona» otmenila kontserty v Krasnojarske i Kemerove po trebovaniju prokuratury. - Afiša Daily 13.11.2018. https://daily.afisha.ru/news/21526-gruppafrendzona-otmenila-koncerty-v-krasnoyarske-i-kemerove-po-trebovaniyu-prokuratury/

Nikitin, Andrei (2009), 25/17 My pobedim. - Rap.ru 5.10.2009. http://www.rap.ru/reading/434

Nikitin, Andrei (2010), Grot: Nikomu ne nužnyje slova. - Rap.ru 21.4.2010. http://www.rap.ru/ reading $/ 384$

RIA Novosti (2017), Battl Oxxxymiron protiv Gnoinogo nabral boleje 3 mln prosmotrov za notš. - Ria Novosti 14.8.2017. https://ria.ru/20170814/1500306509.html

RIA Novosti (2018), Reper Haski vyšel iz spetsprijemnika po rešeniju suda. - Ria Novosti 28.11.2018. https://ria.ru/20181126/1533545110.html

Sajapina, Rita (2008), Ulitšnyje propovedniki. 14.8.2008. https://blednyi-2517.livejournal.com/2499. $\mathrm{html}$

Šenkman, Jan (2017), Šekspir, Navalnyi i Gnoinyi. - Novaja gazeta 15.8.2017. https://www.novayagazeta.ru/articles/2017/08/15/73485-shekspir-navalnyy-i-gnoynyy

Ševelev, Mihail (2016), Ljudi s avtomatami i ljudi s gitarami. - Novaja Gazeta 7.8.2018. https://www. novayagazeta.ru/articles/2018/08/07/77425-lyudi-s-avtomatami-i-lyudi-s-gitarami

TASS (2018), Putin: popytki ogranitšit rep-ispolnitelei ne privedut k položitelnomu rezultatu. - TASS 20.12.2018. https://tass.ru/obschestvo/5935361

Turner, David (2017), Look At Me!: The Noisy, Blown-Out SoundCloud Revolution Redefining Rap. - Rolling Stone 1.6.2017. https://www.rollingstone.com/music/music-features/look-at-methe-noisy-blown-out-soundcloud-revolution-redefining-rap-123887/

United Nations Office on Drugs and Crime (UNODC). World Drug Report 2009. NY: United Nations, 33-61. http://www.unodc.org/documents/wdr/WDR_2009/WDR2009_eng_web.pdf.

Walker, Shaun (2012). The Man who was raised in Slough and raps in Russia. - Independent 17.11.2012. https://www.independent.co.uk/news/world/europe/the-man-who-was-raised-in-slough-and-rapsin-russia-8324127.html 